\title{
QUANTITATIVE EFFECTS OF THE SHALE OIL REVOLUTION
}

Cristiana Belu Manescu and Galo Muno.

Documentos de Trabajo. N. 1518

\section{baneo gespaña}

\author{
Eurosistoma
}

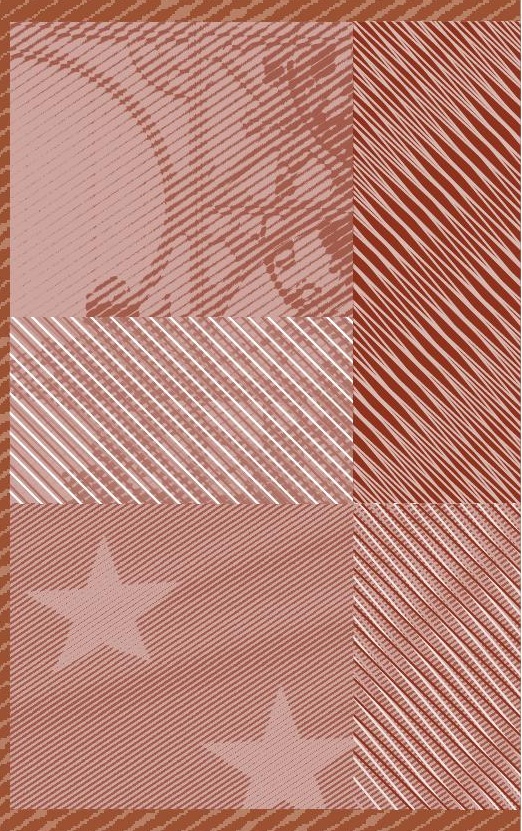


QUANTITATIVE EFFECTS OF THE SHALE OIL REVOLUTION 
QUANTITATIVE EFFECTS OF THE SHALE OIL REVOLUTION ${ }^{(*)}$

Cristiana Belu Manescu ${ }^{(*)}$

EUROPEAN COMMISSION

Galo Nuño ${ }^{(* \star)}$

BANCO DE ESPAÑA

$\left.{ }^{*}\right)$ The views expressed in this manuscript are those of the authors and do not necessarily represent the views of the European Commission, the Banco de España or the Eurosystem. The authors are very grateful to Anton Nakov, Livio Stracca, Frauke Skudelny, Ine Van Robays, two anonymous referees, participants at the CAMP Workshop 2014 on «Commodity Price Dynamics and Financialization» in Oslo and seminar participants at the European Central Bank and the Banco de España for helpful comments and suggestions. All remaining errors are ours.

$\left.{ }^{* *}\right)$ European Commission. Directorate-General Economic and Financial Affairs, Communications Unit, B-1049 Bruxelles / Brussels (Belgium). Email: cristiana.manescu@ec.europa.eu.

${ }^{\star \star \star *}$ Banco de España, Alcalá 48, 28014 Madrid (Spain). Email: galo.nuno@bde.es. 
The Working Paper Series seeks to disseminate original research in economics and finance. All papers have been anonymously refereed. By publishing these papers, the Banco de España aims to contribute to economic analysis and, in particular, to knowledge of the Spanish economy and its international environment.

The opinions and analyses in the Working Paper Series are the responsibility of the authors and, therefore, do not necessarily coincide with those of the Banco de España or the Eurosystem.

The Banco de España disseminates its main reports and most of its publications via the Internet at the following website: http://www.bde.es.

Reproduction for educational and non-commercial purposes is permitted provided that the source is acknowledged.

C BANCO DE ESPAÑA, Madrid, 2015

ISSN: 1579-8666 (on line) 


\section{Abstract}

The aim of this paper is to analyse the impact of the so-called «shale oil revolution» on oil prices and economic growth. We employ a general equilibrium model of the world oil market in which Saudi Arabia is the dominant firm, with the rest of the producers as a competitive fringe. Our results suggest that most of the expected increase in US oil supply due to the shale oil revolution has already been incorporated into prices and that it will produce an additional increase of 0.2 percent in the GDP of oil importers in the period 2010-2018. We also employ the model to analyse the collapse in oil prices in the second half of 2014 and conclude that it was mainly due to positive unanticipated supply shocks.

Keywords: Saudi Arabia, general equilibrium, shale oil.

JEL classification: Q41, Q47, E17. 


\section{Resumen}

El objetivo de este trabajo es analizar el impacto de la llamada «revolución del petróleo no convencional» sobre los precios del petróleo y el crecimiento económico. Para ello se utiliza un modelo de equilibrio general del mercado internacional de crudo en el que Arabia Saudita es el productor dominante, actuando los restantes productores como precio-aceptantes. Nuestros resultados sugieren que los precios del crudo ya han incorporado la mayor parte del incremento esperado en la producción de crudo no convencional norteamericana, y que esto producirá un aumento del 0,2 \% del PIB de las economías importadoras de petróleo durante el período 2010-2018. También empleamos el modelo para analizar el colapso en los precios del crudo ocurrido en la segunda mitad de 2014 y concluimos que fue debido principalmente a perturbaciones no anticipadas de la oferta de crudo.

Palabras clave: Arabia Saudita, equilibrio general, petróleo no convencional.

Códigos JEL: Q41, Q47, E17. 


\section{Introduction}

Oil markets have recently undergone a significant transformation with the unexpectedly strong rise in the US production of shale oil. Shale oil refers to conventional oil (light oil with low sulphur content) trapped in very low-permeability tight formations known as shales, which makes extraction difficult. The combination of horizontal drilling techniques together with hydraulic fracturing, developed in the 1970s, and rising oil prices have made the exploration and exploitation of large volumes of shale oil possible. Shale oil is only one subset of a broader category of unconventional oil, known as "tight oil", trapped in a variety of very low-permeability formations, whose extraction has been made possible by technological advances. However, the convention in the press is to use the terms "shale oil" and "tight oil" interchangeably when referring to oil extracted from all low-permeability formations (i.e. not only oil from shale formations). We follow this convention throughout the paper and refer to the entire tight oil category as "shale oil."1

In the Unites States, the extraction of shale oil has grown dramatically over the last few years taking the market by surprise. In 2013, the Unites States is estimated to have produced $3.5 \mathrm{mb} / \mathrm{d}$ of shale oil which is three times higher than the amount it produced in 2010 (EIA, 2014). By 2020, US shale oil is estimated to reach $4.8 \mathrm{mb} / \mathrm{d}$, representing about a third of total US supply. This is having profound implications for the US economy, in terms of higher US energy independence and a decline in its trade deficit. More generally, from a global perspective, this has been a major factor supporting non-OPEC supply growth and contributing to the relative stability of Brent oil prices until mid-2014. Moreover, although the United States is expected to remain the dominant shale oil producer for the next decade, technically recoverable shale oil resources are estimated to be abundant also outside the United States (five times the size of US shale oil resources according to EIA, 2013).

In response, a rich body of academic and non-academic literature by investment banks, energy companies, national and international organizations and energy pundits has emerged in an attempt to assess the magnitude and implications of the shale oil revolution. Most studies concentrate on the difficult task of estimating the size of shale oil production and resources (e.g. EIA, 2014, IEA, 2013 and earlier studies) or analyze the factors which caused the shale oil revolution to occur in the United States and not elsewhere (e.g. Alquist and Guenette, 2014, Maugeri, 2012). Several studies use global econometric models to estimate wider economic implications of the shale oil revolution (PWC, 2013), whereas a few focus on the impact on oil prices, usually gauged by relatively simple methods (e.g. Sharenow and Worah, 2013, PWC, 2013). We complement these works by using a

\footnotetext{
${ }^{1}$ Unless otherwise stated, by shale oil we refer to what the Energy Information Administration (EIA) calls "tight oil" and the International Energy Agency (IEA) calls "light, tight oil." The term tight oil does not have a specific technical, scientific, or geologic definition. Tight oil is an industry convention that generally refers to oil produced from very low-permeability shale, sandstone, and carbonate formations. Some of these geologic formations have been producing low volumes of oil for many decades in limited portions of the formation.
} 
state-of-the-art general equilibrium model to assess the impact of shale oil on oil prices and GDP. We employ the model of Nakov and Nuno (2014) in which the oil market is characterized by the presence of a dominant supplier with a competitive fringe and which has been shown to fairly well replicate the dynamics in the oil market. ${ }^{2}$ The key advantage of our model is that the reaction of Saudi Arabia is embedded in the model. Saudi Arabia is the largest OPEC producer and also has the largest spare capacity which gives it substantial power among OPEC members to influence markets. As a result, the price impact of shale oil will necessarily depend on the response of Saudi Arabia. In contrast to similar existing studies which typically make an explicit assumption about Saudi Arabia (PWC, 2013), in our framework the response of Saudi Arabia is endogenously determined.

We assess the impact of the shale oil revolution under three scenarios for US shale oil projections until 2018: a baseline scenario using the EIA (2014) projections of US shale oil and two alternative scenarios to capture the uncertainty surrounding the baseline projection. In all three cases we assume that Saudi Arabia maximizes its discounted flow of profits. Our results suggest that (i) most of the shale oil revolution has already been incorporated into oil prices, and (ii) even considerable anticipated changes in the scale of the production will have only a small effect on prices. The oil price impact of the increase in shale supply under the different scenarios amounts to changes of less than $\pm \$ 4$ per barrel $(\mathrm{pb})$. The relatively muted impact on prices onwards stems mainly from the anticipated nature of the shock and from the contraction in non-shale world oil supply, largely from Saudi Arabia, which helps to moderate the change in world oil production and sustain prices. According to the model, in response to lower oil prices and a reduced oil market share, Saudi Arabia curbs its investment in new production capacity which leads to a deterioration in its spare capacity position. Finally, the model suggests that the shale oil revolution will produce an increase of 0.2 percent in the GDP of oil importers by 2018, compared to 2010 .

If most of the shale oil revolution is already priced-in and therefore its impact on current price dynamics is negligible, how can we explain the collapse in oil prices in 2014? We discuss three complementary explanations: (i) the increase in non-US supply that happened in the second half of 2014; (ii) the global economic slowdown, which depressed most commodity prices; and (iii) the deviation of Saudi Arabia from its optimal rule as it decided not to reduce its production in order to accommodate the increase in supply by other producers. These three factors were unanticipated in contrast to the anticipated nature of the shale oil revolution, at least since 2010-11. We take the model to the data on oil prices and quantities in order to quantify the relative impact of these three factors. We conclude that supply factors played the largest role.

\footnotetext{
${ }^{2}$ A large portion of the literature suggests that the 'dominant supplier with competitive fringe' view of the oil industry is the one that best describes the empirical evidence. Examples include Mabro (1975), Dahl and Yücel (1991), Adelman (1995), Alhajji and Huettner (2000a,b) and Brémond, Hache and Mignon (2011).
} 
The analysis of the 2014 collapse in oil prices complements the existing literature analyzing this episode, based on structural VARs. Badel and McGillicuddy (2015) and Baumeister and Kilian (2015) conclude that demand shocks played the major role. In contrast, Baffes et al. (2015) find that supply shocks accounted for roughly twice as much as demand shocks in explaining the drop in oil prices during the recent episode.

This paper relates to the literature on general equilibrium models that explicitly analyze the oil market. Recent examples include Backus and Crucini (2000), Blanchard and Gali (2010), Bodenstein et. al. (2011), Bodenstein and Guerrieri (2011), Bodenstein at al. (2012), De Miguel and Manzano (2006), Leduc and Sill (2007) and Nakov and Pescatori (2010a,b).

The structure of the paper is as follows. Section 2 describes the magnitude and importance of the shale oil revolution. Section 3 introduces the model and the shale oil production scenarios and discusses the main results. Section 4 analyzes the 2014 episode. Section 5 discusses the policy implications. Finally, section 6 concludes.

\section{The transformational impact of US shale oil for the oil market}

\subsection{The size of the US shale oil revolution}

In the United States, the production of shale oil has grown dramatically over the last few years. In 2013, the Unites States is estimated to have produced $3.5 \mathrm{mb} / \mathrm{d}$ of shale oil, which is three times as much as in 2010 (EIA, 2014). This accounted for nearly half of US crude oil supply and almost a third of its total oil supply in 2013 (see Figure 1). As a result, shale oil put an end to a prolonged period of declining supplies: the Unites States has for the first time produced more oil in 2013 than in 1985. Looking ahead, US shale-oil production is expected to continue to rise and peak at $4.8 \mathrm{mb} / \mathrm{d}$ in 2020 according to the EIA (see Table 1), before gradually declining to $3.2 \mathrm{mb} / \mathrm{d}$ by 2040 .

From a global perspective, the rapid rise of US shale oil has been the main driver behind the increase in non-OPEC supply (see Figure 2). During 2009-2012, US oil supply grew, on average, at a sustained annual rate of $6.7 \%$, while non-OPEC oil supply produced outside the Unites States was stable, on average. ${ }^{3}$ The US share in total non-OPEC supply jumped to more than a quarter in 2012, compared to just over a fifth in 2008. In 2012, US shale oil accounted for $2.5 \%$ of world oil supply.

Despite its impressive volume, the shale oil revolution was largely unexpected. For example, in its latest 2014 Annual Energy Outlook, the EIA projects US shale oil production at $4 \mathrm{mb} / \mathrm{d}$ in

\footnotetext{
${ }^{3}$ At the time of writing, the latest EIA data for shale oil are for 2012, while data for 2013 onwards are projected (see EIA, 2014).
} 
2014, which is nearly three and a half times higher that the amount forecast two years ago (see Table 1). Similarly, the International Energy Agency (IEA) in its 2013 report revised its estimates for 2012 up by $30 \%$ from those in its 2012 one (see IEA 2012a and 2013). This is not surprising, however, given that forecasts of shale oil production are critically influenced by assumptions about the remaining unproved technically recoverable resources, which, with a short history of well data, can be extremely imprecise. As more information about the well production becomes available, the size of revisions to shale oil production projections is expected to diminish. Indeed, the size of forecast revisions was much smaller in 2014 than in 2013 (see Table 1 or EIA, 2014).

The persistent high levels of oil prices in recent years made shale oil exploration economically viable. However, several factors were in place in the Unites States that allowed the shale oil revolution to occur first there and not elsewhere: a history of shale gas exploitation, legal incentives for landowners and an advanced oil production infrastructure (see Alquist and Guenette, 2014). First, the technology necessary for shale oil exploitation started to be developed in the early 19th century, when it was aimed at shale gas exploration, and was perfected during the 1980s. Second, the Unites States has legal and institutional features - such as private ownership rights and easy access to global capital market funding - that make the economic environment attractive for the extraction of unconventional oil. Third, the Unites States possesses a unique infrastructure setting consisting of a large number of state-of-the-art drilling rigs, an extensive pipeline network, and associated refineries, which is key to ensuring a rapid expansion in production.

Outside the Unites States, shale oil production is expected to take off only slowly, despite the fact that technically recoverable resources of shale oil are estimated to be abundant worldwide (five times the size of the ones in the Unites States according to EIA, 2013). ${ }^{4}$ Companies are hinting at good prospects in Russia, China and Argentina, which are estimated together to hold $46 \%$ of the technically recoverable resources of shale oil outside the Unites States. The primary reason for this is that technically recoverable resources are different from economically recoverable resources, owing to three important factors: the cost of production, the quantity produced by any given well and the market price of oil. As mentioned, the experience with shale oil production in the Unites States highlights that economic recoverability can be significantly influenced by above-the-ground factors (property rights, infrastructure, etc.) as well as by geology, which vary greatly around the globe. This is also reflected in the wide range of the estimated price required to render shale oil exploitation profitable (at $\$ 45-80$ pb, according to IEA, 2012a). Nevertheless, the unconventional technologies used for shale oil extraction could be used to boost the production of existing conventional oil fields globally.

\footnotetext{
${ }^{4}$ Whereas in the rest of the paper by shale oil we refer to both shale and tight oil, the shale oil reserve estimates refer exclusively to oil from shale oil formations.
} 


\subsection{The short-term impact of the shale oil revolution}

The surge in US unconventional oil production has had a major impact on the US economy. First, a major importer of oil and natural gas since the 1970s, the Unites States is projected to significantly reduce its energy import dependency. This would entail a reduction in the US trade deficit. The US self-sufficiency ratio, defined as the ratio of indigenous energy production divided by total primary energy demand, is expected to rise from just under 80 percent in 2010 to 97 percent by 2035 which stands in contrast to developments in other regions (China, India, and the European Union) which will become less self-sufficient. Overall, the IEA estimates that US net energy import volumes could fall from $9.5 \mathrm{mb} / \mathrm{d}$ in 2011 to $3.4 \mathrm{mb} / \mathrm{d}$ in $2035 .^{5}$ At the same time, a reduction in US net oil imports would also affect global oil supply indirectly, as supply usually directed to the Unites States would become available for other buyers.

Second, the rising oil supply led to a collapse in the spread between the WTI, the US crude oil price benchmark, and international benchmarks. Prices of the WTI and Brent crude oil benchmarks have historically been related, with the WTI trading at a slight premium (\$1-2 pb) owing to higher quality and stronger product demand. This historical relationship collapsed in 2011. Limitations in the US crude pipeline system and increasing oil flows to the WTI benchmark pricing hub at Cushing, Oklahoma, helped push WTI to a discount of $\$ 16$ pb to Brent forward crude on average during 2011 which persisted in 2012. More recently, however, increased pipeline and rail capacity eased the transport bottlenecks in the landlocked US midcontinent, narrowing the discount to Brent to less than $\$ 8$ pb in May 2014 .

At the global level, the surge in supply from US shale sources was an important factor contributing to the relative stability of Brent oil prices observed from 2011 until mid-2014. Despite substantial and repeated supply disruptions in major OPEC producers (e.g. Libya, Iran) that temporarily spiked oil prices, Brent oil prices remained remarkably resilient in the range of $\$ 100-115$ pb during that period. ${ }^{6}$ In addition to the mitigating impact of the fast-rising shale oil supplies, estimated to have added 3.9\% to total oil supply in 2013, demand-side factors also played a role. The slow economic recovery in advanced economies after the financial crisis, coupled with the slowdown in emerging economies, reduced the growth in oil demand. Indeed, according to the IEA, global oil demand increased only 1.1\% per annum on average between 2011 and 2013, compared to a strong $1.5 \%$ per annum during the period 2005-2007.

\footnotetext{
${ }^{5}$ See IEA (2012b).

${ }^{6}$ For example, Libya lost a significant share of its supply both in 2013 and 2011 due to political uncertainty (1.3 $\mathrm{mb} / \mathrm{d}$ in 2011 and $0.5 \mathrm{mb} / \mathrm{d}$ in 2013), while sanctions by Western nations on Iranian oil exports reduced Iranian supply by $0.7 \mathrm{mb} / \mathrm{d}$ in 2012 .
} 


\section{The long-term impact of the shale oil revolution: a DSGE model of the global oil market}

The long-term impact on oil prices of further rising shale oil supplies is, however, far from clear and will crucially depend on the reaction of Saudi Arabia. Saudi Arabia is one of the largest players in the global oil market: it produces more than a tenth of the world's oil output and owns a quarter of the world's proven reserves. The Kingdom is also a key OPEC member, typically playing a central role in OPEC's decision-making. Saudi Arabia's spare capacity is much larger than the aggregate spare capacity of the rest of the oil producers. In addition, as discussed in Nakov and Nuño (2014), it typically acts as a "swing producer" in the oil market, increasing its production in the face of supply disruptions in other producers or rises in demand, and reducing it in the opposite case.

General equilibrium effects are therefore key to understanding the effect of the increase in shale oil production in the United States; in particular, the response of Saudi Arabia is especially relevant. In this paper we employ the model introduced in Nakov and Nuño (2014) to analyze the oil market. The model comprises three regions: one oil-importing and two oil-exporting. The oil-importing region imports oil for use in consumption, and employs labor and capital in the production of final goods, some of which are consumed domestically, the rest being exported to the two oil-producing regions. The model is summarized in the Appendix. Oil is a homogeneous commodity supplied by a dominant supplier and a fringe of competitive oil producers. The fringe take the oil price as given when choosing their production level. The dominant supplier faces a downward sloping residual demand curve and picks the profit-maximizing points on that curve at each point in time and in each state of nature. Oil exporters produce oil only and their revenue is recirculated to the oil-importing region in the form of demand for final consumption and investment goods.

The dominant supplier is aware that it can manipulate $\grave{a}$ la Stackelberg the choices both of the competitive fringe, and of the oil importer. For example, the dominant supplier understands that a change in its own oil supply will have an impact on oil demand, oil supply by fringe producers, and the oil price. Except for the difference in market power, which is founded on a technological gap between the two types of oil producers, the competitive fringe and the dominant supplier are modelled symmetrically.

\subsection{Scenarios}

In order to introduce the different scenarios into the model, we calibrate the shocks for the oil production technology of the fringe producers in order to replicate the increase in supply due 
to the shale oil revolution. These shocks are assumed to be anticipated since the beginning of the period (i.e. 2010). It implies that the agents in the model know in advance what the rate of production of shale oil will be in the coming years and that they may take their decisions accordingly in a forward-looking way.

We consider one baseline and two alternative scenarios for the size of shale oil supply, based on the EIA projections published in its Annual Energy Outlook (EIA, 2014). We rely on EIA estimates of US shale oil supply because, unlike other international institutions such as the IEA, the EIA also provides detailed historical data on the production of US shale oil, which facilitates the understanding of recent developments from a historical perspective.

The baseline scenario is calibrated so that shale oil production in the Unites States increases from roughly zero in 2010 to $2.7 \mathrm{mb} / \mathrm{d}$ in 2014 and reaches a peak of $4 \mathrm{mb} / \mathrm{d}$ in $2018 .{ }^{7}$ This scenario assumes that current law and regulations affecting the energy sector remain in place throughout the projection horizon. It also assumes that the production of shale oil remains concentrated in the Unites States and does not extend significantly to other countries before 2018. Second, in the lower shale production scenario we consider the case in which technical or environmental constraints limit US shale production which remains broadly flat at 3mb/d during the 2014-2018 period. Finally, in the higher shale production scenario we assume that technological progress and economic incentives push US shale production up, to $6 \mathrm{mb} / \mathrm{d}$ by 2018 .

The choice of the alternative scenarios is, to some extent, arbitrary because essentially they are meant only to suggest the possible range of the price impact in the event that future shale oil supplies turn out to be different from the baseline. While the magnitude of the alternative scenarios does not necessarily correspond to alternative scenarios proposed in the literature, the asymmetric bounds were chosen on purpose to reflect the idea that, in light of historical revisions, there is a higher chance that shale oil supply will surprise on the upside than on the downside.

\subsection{Results}

Figure 3 shows the difference between the long-run path followed by oil production and prices in the three scenarios and the counterfactual path in the case of no shale oil production. The period of interest is 2014-2018, but we assume, in line with the data, that shale oil production began in 2010. In the upper left panel we display the alternative scenarios for the production of shale oil described above.

The model analysis suggests that oil prices in 2014 already incorporated most of the reduction due to the increase in the oil supply. In the upper right panel of the figure, we display the evolution of oil prices (relative to the counterfactual path). In the baseline scenario, most of the impact of

\footnotetext{
${ }^{7}$ Notice that we are subtracting $0.8 \mathrm{mb} / \mathrm{d}$ in all years in order to remove the "pre-revolution" residual production of shale oil.
} 
the expected increase in oil production was already incorporated into 2014 prices, which were $\$ 5$ $\mathrm{pb}$ below the counterfactual path. There is only an additional decline of less than $\$ 1 \mathrm{pb}$ before the end of 2015 and then prices slowly revert. This means that, from the perspective of 2014 oil prices, the anticipated increase of $1 \mathrm{mb} / \mathrm{d}$ until 2018 has almost no effect on long-run oil prices.

This effect is more striking in the case of the lower production scenario, where prices revert back to around $-\$ 3$ pb by 2018 . In contrast, in the higher production scenario there is still room for price decreases, reaching levels below $-\$ 9$ pb by 2017 . These bounds based on our alternative scenarios are roughly $\pm \$ 4 \mathrm{pb}$ around the baseline.

The relatively muted impact on prices from 2014 onwards stems from the anticipated nature of the shocks and from the contraction in non-shale world oil supply, primarily from Saudi Arabia, which helps to moderate the change in overall world oil production and sustain prices. The lower panels of Figure 3 display the total world production and the production of Saudi Arabia. In 2014, of almost $3 \mathrm{mb} / \mathrm{d}$ of shale oil, around $1 \mathrm{mb} / \mathrm{d}$ were expected to be offset by Saudi Arabia and another $0.5 \mathrm{md} / \mathrm{d}$ by the rest of producers due to the lower oil prices. The result was a net expansion of just $1.5 \mathrm{mb} / \mathrm{d}$ compared to the no shale oil counterfactual scenario, since half of the increase in oil production in the Unites States was offset either by Saudi Arabia or by higher marginal cost producers being expelled from the market due to the $\$ 5$ fall in prices.

The amount of the reduction in oil supply by Saudi Arabia increases with time as this is its profit-maximizing path. In the baseline scenario, by 2018, Saudi Arabia should be producing around $1 \mathrm{mb} / \mathrm{d}$ less than in 2014, which would completely offset the increase in shale oil production. In the lower and higher shale production scenarios, Saudi Arabia should also reduce its production by a further $0.5 \mathrm{mb} / \mathrm{d}$ and $1.5 \mathrm{mb} / \mathrm{d}$, respectively, by 2018 .

Apart from the impact on prices and quantities, the shale oil revolution also affects Saudi Arabia's spare capacity. Spare capacity provides a buffer to smooth supply and demand shocks. Our baseline model simulation indicates that spare capacity should have risen slightly in 2014 as a result of the reduction in Saudi Arabia's production (see Figure 4). Thereafter, however, spare capacity declines. The explanation is that lower oil prices and a reduction in Saudi Arabia's oil market share lower its capital investment in new production capacity, which eventually leads to a gradual decline in its spare capacity. In conclusion, the spare capacity of Saudi Arabia is projected to decline in response to lower oil prices and lower capital investment. Only in the higher shale scenario is there still room for an additional increase in capacity, peaking in mid-2016.

The shale oil revolution also impacts the GDP of oil importers. As discussed in the Appendix, the model considers an aggregate block of "oil importers" without distinguishing between advanced and emerging economies. We compute a cumulative impact equivalent to 0.2 percent of 2010 GDP by 2018. This amount is the result of three different effects. The first one is the direct impact of a change in the terms-of-trade between importers and exporters due to the decline in oil prices. 
This effect is clearly growth-enhancing. The second effect is the fall in the imports of oil exporters due to the fall in their demand. This second effect is growth-reducing for oil importers. Finally, the third effect is related to the impact that lower energy prices may have on the consumption and leisure decisions of households, and its impact on growth is much more difficult to predict. It should be stressed that alternative assumptions about the structure of financial markets or the consumption-leisure elasticities may increase the impact on GDP, so that this result should be read as a lower bound of the true impact in the real world.

\subsection{Robustness to the demand elasticity}

We also consider a robustness check. As discussed in the calibration part of the Appendix, the short-run price elasticity of oil demand in the model is $\frac{P}{O} \frac{\partial O}{\partial P}=\frac{1}{\eta}=0.25$, consistent with Kilian and Murphy's (2014) estimates. However other papers, such as Smith's (2009), provide an estimate of the price elasticity of oil demand of about 0.05 . We denote this second case as "low demand elasticity". Here we assess how sensitive our results are to changes in the demand elasticity. ${ }^{8}$

Figure 5 displays the results. In this case the anticipated effect of the increase in shale supply is still larger, reaching almost $\$ 9$ pb in 2014 and forcing Saudi Arabia to reduce its production by $2 \mathrm{mb} / \mathrm{d}$. However, looking ahead the dynamics described in the baseline case are even more patent. Saudi Arabia should again offset more than $1 \mathrm{mb} / \mathrm{d}$ between 2014 and 2018 so that total oil production decreases slightly during the period. Oil prices increase by $\$ 2 \mathrm{pb}$. Therefore, it seems that the main conclusions are reinforced in the case of low demand elasticity.

\section{The collapse in oil prices in 2014}

Brent oil prices collapsed from a level of $\$ 105$ pb in June 2014 to less than $\$ 60$ pb in December. Given this major decline, the conclusion that most of the current and expected increase in US supply due to the shale oil revolution had already been incorporated into oil prices may seem surprising. However, several additional factors to the shale oil revolution may account for this decline:

1. Unanticipated supply shocks. Several major producers experienced large increases in their production in the second half of the year. In Libya, for example, rebel militias announced in July an end to their 11-month blockade of vital oil terminals that had crippled oil production. ${ }^{9}$ Iraq increased its production by almost $0.5 \mathrm{mb} / \mathrm{d}$ between June and De-

\footnotetext{
${ }^{8}$ To this end, we set $\eta=21$ and recalibrate the supply shocks in the baseline case to 0.0052 from January 2010 to December 2017 and 0.0045 thereafter. See the Appendix for the baseline calibration.

${ }^{9}$ Libya's state-owned NOC on 6 July lifted force majeure - a waiver of contractual obligations - at the eastern ports of Ras Lanuf and Es Sider.
} 
cember despite the conflict with the so-called Islamic State for Iraq and Syria (ISIS). Other non-OPEC producers such as Russia, Canada, Norway and the UK also increased their output during the period. The total increase in oil supply from June to December for all the producers bar the Unites States was roughly $1.5 \mathrm{mb} / \mathrm{d}$ (see Figure 6), compared to a US increase of $0.6 \mathrm{mb} / \mathrm{d}$.

2. Unanticipated demand shocks. During 2014 there were a number of negative surprises to the global economic growth rate which forced the IEA to revise downwards its oil demand forecasts. This global slowdown produced a decline in the prices of many commodities, including metals and foodstuffs, during the second half of the year. In addition, the strong appreciation of the US dollar increased the real price of oil in other currencies, thus reducing the demand for oil.

3. Surprise Saudi Arabia reaction. As discussed above, in a context of positive supply and negative demand shocks, the optimal profit maximizing strategy for Saudi Arabia is to partially reduce its production in order to prevent the collapse in oil prices. ${ }^{10}$ This time however Saudi Arabia strongly signalled its reluctance to sacrifice market share in order to defend prices. At its 166th meeting on 27 November, OPEC as a whole decided to maintain the quotas unchanged due to the adamant position of Saudi Arabia, despite rising pressures from other members such as Iran or Venezuela to reduce them. Figure 6 displays how Saudi Arabia only reduced its output by $0.05 \mathrm{mb} / \mathrm{d}$ from June to December. Apparently, Saudi Arabia is trying to avoid repeating the events in the early 1980s, when it systematically lost output share in order to defend prices amid a generalized increase in oil production. ${ }^{11}$ It could be the case that Saudi Arabia has decided that the current situation with shale oil is similar to the one in the 1980s and that it may be beneficial to deviate from its profit maximizing strategy in order to adopt a constant share rule. This would expel some shale oil producers from the market, avoiding demand substitution by renewable sources and weakening the position of regional rivals such as Iran.

\footnotetext{
${ }^{10}$ See also Nakov and Nuño (2014).

${ }^{11}$ Higher prices during the 1970s and early 1980s, following the first and second oil shocks, caused oil supply in non-OPEC countries to increase significantly (e.g. in the Soviet Union, Norway, Mexico, China and the UK). In response to this, OPEC decided to lower its production via a quota system, in an attempt to defend prices. This notwithstanding, oil prices continued to fall. Moreover, Saudi Arabia had to absorb most of these reductions as many OPEC members were still producing above their quotas. Indeed, at its lowest in 1983, Saudi Arabia's output was nearly $8 \mathrm{mb} / \mathrm{d}$ down from the beginning of 1981. The combination of lower prices and declining production substantially reduced Saudi Arabia's revenues, which fell by more than $80 \%$ from January 1981. In September 1985 , Saudi Arabia decided to raise production in an effort to discipline the other producers. Over the next year, its output increased by more than $4 \mathrm{mb} / \mathrm{d}$ with dramatic effects on oil prices, which declined more than $50 \%$ over the period (known as the third oil shock), from $\$ 28$ to $\$ 12 \mathrm{pb}$. Thus, the sharp fall in oil prices fully offset the rise in output, which kept Saudi oil revenues constant.
} 
In order to assess the relative importance of each of these factors in the decline in prices, we employ the DSGE model. We augment the model in order to include unanticipated supply and demand shocks as well as deviations from Saudi Arabia's optimal strategy. ${ }^{12}$ The model is solved by first order perturbation methods and the resulting linear state space model is embedded into a Kalman filter. In order to compute the realizations of the three shocks (supply, demand and Saudi Arabia) we consider three observed series: (i) growth in real oil prices; (ii) growth in world oil production; and (iii) Saudi Arabia's share in oil production. We employ monthly data from January 1973 to December 2014. The Kalman filter allows us to identify the most likely paths of the shocks in order to generate the observed time series. Then we employ each of these shocks to compute the relative contributions to real oil prices.

Figure 7 displays the results. The three factors discussed above each contributed to the decline in prices, with the largest contribution stemming from supply shocks. Demand shocks also play an important role, whereas the reaction of Saudi Arabia seems to have played a minor role in this particular episode. These results suggest that the recent decline in prices was mainly due to the large increase in oil production by non-US producers (as the increase in shale oil was already priced-in) against a background of demand slowdown.

\section{$5 \quad$ Policy implications}

The shale oil revolution and the recent decline in oil prices affect economic growth in a countryspecific way, and thus the policy prescriptions should vary accordingly.

The losers are the traditional oil exporters. Figure 8 displays the share of oil exports in GDP for a sample of major oil exporters. A decline by half in the price of oil may produce GDP contractions as large as 20-25\% for countries such as Kuwait and Venezuela. Some of these countries, such as Saudi Arabia and Kuwait, have large sovereign wealth funds (SWFs) that may help to cushion the fall in prices but others are more exposed to this negative shock.

Once again, the important role of Saudi Arabia in the future evolution of oil prices should be highlighted. In 2014, in contrast with the long-run predictions of the model, Saudi Arabia has decided not to accommodate the increase in oil supply, in an attempt to defend market share and to expel some high cost producers from the market. This is a strategy aimed at curbing new investment in exploration, avoiding demand substitution towards alternative energy sources and improving its relative position vis-à-vis some of its geopolitical competitors such as Iran. However, in the short-run the Saudis are facing a major loss of revenues that, if long-lasting enough, may destroy all the wealth accumulated during the boom years.

\footnotetext{
${ }^{12}$ Due to their negligible short-run effect, we ignore the shale oil shocks. The extension is explained in the Appendix.
} 
The main winner is naturally the United States. The US shale oil supply is estimated to be around $4 \mathrm{mb} / \mathrm{d}$ in 2014. Assuming an average price of $\$ 100 \mathrm{pb}$, this amounts to more than $\$ 146$ billion in oil revenues or roughly 0.8 percent of US GDP. This is a major transfer of resources from the rest of the world to the US economy that not only boosts economic growth but also helps to reduce the US current account deficit. Beyond the direct impact, there is a full range of secondround effects on the US economy associated with the development of new ancillary industries and the increase in employment associated, directly or indirectly, with the shale oil sector.

Oil-importing countries such as Japan, India, China and most European countries are also indirect winners of the shale revolution and the recent drop in prices. The decrease in oil prices will help to reduce energy imports and to increase GDP growth, as highlighted by Figure 8. However, two important caveats should be mentioned. The first one relates to the recycling of petrodollars. Many oil exporters have large amounts of accumulated wealth in real and financial assets in oil-importers through SWFs. The decline in oil revenues will probably reduce the exposure to such assets, reducing their price. In a context of high private and public debt levels, a fall in debt prices (a rise in yields) may have contractionary effects due to the increased costs of debt servicing. The second point relates to the current situation in many advanced economies, where short-term nominal interest rates are close to the zero lower bound (ZLB) and inflation rates are very low or even negative. A decline in oil prices may introduce additional deflationary pressures, producing a hike in real interest rates that may hurt economic growth. ${ }^{13}$ Therefore, central banks in oil-importing countries should be ready to act in the event that further declines in oil prices that may threaten the economic recovery.

\section{Conclusions}

Oil markets have recently undergone a significant transformation with the rise in the US production of shale oil, which is expected to pick up and to reach around $4.8 \mathrm{mb} / \mathrm{d}$ by 2020, i.e. about a third of total US supply, according to the EIA. This paper assesses the impact of the "US shale oil revolution" on global oil prices and quantities, which ultimately depends on two key factors: 1) the quantity of oil that is eventually produced, subject to environmental and technological risks and 2) the response of Saudi Arabia to sustain prices.

To capture the current uncertainty regarding the size of future US shale oil supply, we consider two alternative scenarios, i.e. a lower and a higher shale oil production scenario; this results in some bounds around our baseline projections, which are based on EIA forecasts. Regarding the response by Saudi Arabia to sustain prices, we employ a general equilibrium model that rationalizes

\footnotetext{
${ }^{13}$ The impact of oil prices on inflation and economic activity at the ZLB has been discussed in recent papers such as Bodenstein et al. (2013) and Wieland (2014).
} 
the behavior of Saudi Arabia - the core OPEC producer - as that of a dominant producer with a competitive fringe. The model allows for an endogenous response by Saudi Arabia, thus avoiding having to make specific assumptions on the OPEC response to the surge in global oil supply.

Results suggest that most of the expected increase in oil supply due to the shale oil revolution was already incorporated into oil prices in 2014 and that it will produce an additional increase in the GDP of oil importers of 0.2 percent in 2010-2018. The oil price impact of the increase in shale supply under the different scenarios by 2018 amounts to changes of less than $\pm \$ 4$ pb. The relatively muted impact on prices stems from the anticipated nature of the shock and from the expected contraction in non-shale world oil supply, largely from Saudi Arabia, which helps to moderate the change in world oil production and sustain prices.

Finally, the paper sheds some light on the causes of the collapse in oil prices in the second half of 2014. Our results suggest that the decline was not due to the anticipated increase in shale oil, but to unexpected increases in oil production in a number of major non-US producers against a background of negative demand surprises and unwillingness by Saudi Arabia to accommodate the increase in supply. In particular, we show that non-US supply increased by roughly $1.5 \mathrm{mb} / \mathrm{d}$ between June and December. Therefore, this paper underlines the weak connection between the shale oil revolution, which is an anticipated long-term phenomenon, and the recent collapse in prices, which is the consequence of unanticipated shocks in the market. 


\section{References}

[1] Adelman, M.: 1995. The Genie Out of the Bottle: World Oil Since 1970, The MIT Press.

[2] Alhajji, A. and Huettner, D.: 2000a, OPEC and other commodity cartels: a comparison, Energy Policy, vol. 28, pp. 1151-1164.

[3] Alhajji, A. and Huettner, D.: 2000b, OPEC and world crude oil markets from 1973 to 1994: cartel, oligopoly or competitive?, Energy Journal vol. 21(3), pp. 31-60.

[4] Alquist, R., and Guenett, J.D.: 2014, A blessing in disguise: The implications of high global oil prices for the North American market, Energy Policy, vol. 64(C), pp. 49-57..

[5] Backus, D. and Crucini, M.: 2000, Oil prices and the terms of trade, Journal of International Economics 50(1), 185-213.

[6] Badel, A. and J. McGillicuddy: 2015, Oil Prices: Is Supply or Demand behind the Slump?, On the Economy, Federal Reserve Bank of St. Louis

[7] Baffes, J., M. A. Kose, F. Ohnsorge and M. Stocker: 2015, The Great Plunge in Oil Prices Causes, Consequences, and Policy Responses, Policy Research Note No.1, World Bank.

[8] Baumeister, C. and L. Kilian: 2015, Understanding the Decline in the Price of Oil Since June 2014, CEPR Discussion Paper 10404

[9] Blanchard, O. J. and J. Gali: 2010, The Macroeconomic Effects of Oil Shocks: Why are the 2000s So Different from the 1970s?, in J. Gali and M. Gertler (eds) International Dimensions of Monetary Policy, University of Chicago Press, Chicago, 373-421

[10] Bodenstein, M., and L. Guerrieri: 2011, "Oil Efficiency, Demand and Prices: A Tale of Ups and Downs," International Finance Discussion Papers No. 1031, Board of Governors of the Federal Reserve System.

[11] Bodenstein, M., L. Guerrieri, Luca and C. Gust: 2013, Oil shocks and the zero bound on nominal interest rates," Journal of International Money and Finance, vol. 32(C), pp. 941-967.

[12] Bodenstein, M., Erceg, C. J. and Guerrieri, L.: 2011, Oil shocks and external adjustment, Journal of International Economics, 83(2), 168-184.

[13] Bodenstein, M., L. Kilian, and L. Guerrieri: 2012, Monetary Policy Responses to Oil Price Fluctuations, IMF Economic Review, vol. 60(4), pp. 470-504. 
[14] Brémond, V., E. Hache and V. Mignon: (2011). 'Does OPEC still exist as a cartel? An empirical investigation,' EconomiX Working Papers 2011-5.

[15] Dahl, C. and M. Yucel: (1991). 'Testing alternative hypotheses of oil producer behavior,' The Energy Journal, vol. 12(4), pp. 117-138.

[16] De Miguel, C. and B. Manzano: 2006. Optimal Oil Taxation in a Small Open Economy, Review of Economic Dynamics, 9(3), 438-454.

[17] Energy Information Administration: 2013, Technically recoverable shale oil and shale gas resources: An assessment of 137 shale formations in 41 countries outside the United States, Washington.

[18] Energy Information Administration: 2014, Annual Energy Outlook, Washington.

[19] International Energy Agency: 2008, World energy outlook, OECD, Paris.

[20] International Energy Agency: 2009, World energy outlook, OECD, Paris.

[21] International Energy Agency: 2012a, Medium-term oil market report, OECD, Paris.

[22] International Energy Agency: 2012b, World energy outlook, OECD, Paris.

[23] International Energy Agency: 2013, Medium-term oil market report, OECD, Paris.

[24] Kilian, L., and D. P. Murphy: 2014, The Role of Inventories and Speculative Trading in the Global Market for Crude Oil, Journal of Applied Econometrics, 29(3), 454-478.

[25] Leduc, S. and Sill, K.: 2007, Monetary policy, oil shocks, and TFP: Accounting for the decline in US volatility, Review of Economic Dynamics 10(4), 595-614.

[26] Mabro, R.: 1975, 'Can OPEC hold the line?,' in OPEC and the World Oil Market: The Genesis of the 1986 Price Crisis.

[27] Maugeri, L.:2012. The Shale Oil Boom: A U.S. Phenomenon, Discussion Paper 2013-05, Belfer Center for Science and International Affairs, Harvard Kennedy School.

[28] PWC: 2013, Shale oil: the next energy revolution http://www.pwc.com/en_GX/gx/oil-gasenergy/publications/pdfs/pwc-shale-oil.pdf

[29] Sharenow, G. E. and M. P. Worah: 2013. Shale Oil: A Deep Dive Into Implications for the Global Economy and Commodity Investors http://www.pimco.com/en/insights/pages/shaleoil-a-deep-dive-into-implications-for-the-global-economy-and-commodity-investors.aspx 
[30] Nakov, A. and G. Nuño: 2014, Saudi Arabia and the Oil Market, Economic Journal, 132 (12), 1333-1362.

[31] Nakov, A. and Pescatori, A.: 2010a, Monetary policy tradeoffs with a dominant oil producer, Journal of Money, Credit and Banking, 42(1), 1-32.

[32] Nakov, A. and Pescatori, A.: 2010b, Oil and the Great Moderation, Economic Journal, 120 (543), 131-156.

[33] Smith, J.: 2009, World oil: Market or mayhem?, Journal of Economic Perspectives 23(3), 145164.

[34] Wieland, J. F.: 2014, Are Negative Supply Shocks Expansionary at the Zero Lower Bound?, mimeo. 


\section{Appendix. Model description}

This Appendix is strongly based on Nakov and Nuño (2014): we sketch their model and discuss the particular calibration.

\section{Oil-importing region}

A representative household has a period utility function which depends on consumption, $C_{t}$, oil $O_{t}$, and labor $l_{t}$, and takes the form

$$
U(C, O, l)=\log (C)+\nu_{t} O^{1-\eta} /(1-\eta)-l^{1+\omega} /(1+\omega)
$$

where $\eta$ and $\omega$ are oil demand and labor supply elasticities.

The household faces the period budget constraint

$$
C_{t}+I_{t}+B_{t}+P_{t} O_{t}=w_{t} l_{t}+r_{t}^{k} K_{t-1}+r_{t-1} B_{t-1}
$$

which equates income from labor, $w_{t} l_{t}$, capital, $r_{t}^{k} K_{t-1}$, and bonds, $r_{t-1} B_{t-1}$, to outlays on consumption, $C_{t}$, capital investment, $I_{t}$, new one-period bonds, $B_{t}$, and oil, $P_{t} O_{t} ; P_{t}$ denotes the real price of oil, while $w_{t}$ denotes the real wage. All oil must be consumed within the period of production. Capital is accumulated according to

$$
K_{t}=(1-\delta) K_{t-1}+I_{t}
$$

where $\delta$ is the depreciation rate of installed capital.

The household chooses $C_{t}, O_{t}, B_{t}, I_{t}, K_{t}$, and $l_{t}$, to maximize expected present discounted utility

$$
\max _{C_{t}, O_{t}, B_{t}, I_{t}, K_{t}, l_{t}} E_{o} \sum_{t=0}^{\infty} \beta^{t} U\left(C_{t}, O_{t}, l_{t}\right)
$$

subject to the budget constraint (1), where $0<\beta<1$ is a time preference parameter.

Final goods are produced with labor and capital by a representative price-taking firm, according to

$$
Y_{t}=\left(Z_{t} l_{t}\right)^{\alpha} K_{t-1}^{1-\alpha}
$$

with $0<\alpha<1$. Aggregate total factor productivity $Z_{t}$ evolves according to a deterministic exponential process: $Z_{t}=Z_{t-1} e^{g^{z}}$, where $g^{z}$ is a constant. 
Utility maximization by households implies the following oil demand curve

$$
\nu_{t} C_{t}=P_{t} O_{t}^{\eta},
$$

the labor supply curve

$$
C_{t} l_{t}^{\omega}=w_{t}
$$

and the Euler equations

$$
1=\beta E_{t}\left[\frac{C_{t}}{C_{t+1}}\left(r_{t+1}^{k}+(1-\delta)\right)\right]
$$

and

$$
1=\beta E_{t}\left[\frac{C_{t}}{C_{t+1}}\right] r_{t}
$$

Profit maximization by price-taking firms implies the following labor demand

$$
w_{t} l_{t}=\alpha Y_{t}
$$

and capital demand

$$
r_{t}^{k} K_{t-1}=(1-\alpha) Y_{t}
$$

The region's resource constraint states that total output, $Y_{t}$, must equal the sum of consumption, $C_{t}$, investment, $I_{t}$, and the current account, $\left(P_{t} O_{t}+B_{t}-r_{t-1} B_{t-1}\right)$.

$$
Y_{t}=C_{t}+I_{t}+\left(P_{t} O_{t}+B_{t}-r_{t-1} B_{t-1}\right)
$$

\section{Competitive fringe of oil exporters}

A representative household maximizes the present discounted flow of utility from consumption, ${ }^{14}$

$$
\max _{\tilde{C}_{t}, \tilde{I}_{t}, \tilde{B}_{t}, \tilde{K}_{t}} E_{o} \sum_{t=0}^{\infty} \beta^{t} \log \left(\tilde{C}_{t}\right)
$$

subject to the period budget constraint

$$
\tilde{C}_{t}+\tilde{I}_{t}+\tilde{B}_{t}=\tilde{r}_{t}^{k} \tilde{K}_{t-1}+\tilde{D}_{t}+\tilde{r}_{t-1} \tilde{B}_{t-1}
$$

where consumption, $\tilde{C}_{t}$, and investment, $\tilde{I}_{t}$, are both purchased from the oil-importing region, $\tilde{r}_{t}^{k}$ is the rental price of capital $\tilde{K}_{t}$ rented out by the household to oil firms, $\tilde{B}_{t}$ are one-period bonds that pay an interest of $\tilde{r}_{t}$ and $\tilde{D}_{t}$ are oil firm dividends rebated lump sum to the household.

\footnotetext{
${ }^{14}$ We denote variables belonging to the competitive fringe by tildes (e.g. $\tilde{X}_{t}$ ), and variables belonging to the dominant firm by hats (e.g. $\left.\hat{X}_{t}\right)$.
} 
The household invests in capital according to

$$
\tilde{K}_{t}=(1-\delta) \tilde{K}_{t-1}+\tilde{I}_{t}
$$

A representative fringe firm, owned by the household, maximizes period profits

$$
\tilde{D}_{t}=\max _{\tilde{X}_{t}, \tilde{K}_{t-1}}\left(P_{t} \tilde{O}_{t}-\tilde{X}_{t}-\tilde{r}_{t} \tilde{K}_{t-1}\right)
$$

subject to the production technology

$$
\tilde{O}_{t}=\tilde{Z}_{t} \tilde{u}_{t} \tilde{K}_{t-1}
$$

taking the oil price as given. $\tilde{Z}_{t}$ is the productivity of oil production and $\left(\tilde{u}_{t} \tilde{K}_{t-1}\right)$ is the effective capital in the oil industry, defined as the product of capital utilization $\tilde{u}_{t}$ and installed capital $\tilde{K}_{t-1}$. Productivity $\tilde{Z}_{t}=\tilde{a}_{t} \tilde{Z}_{0} \exp \left(g^{\tilde{z}} t\right)$ follows an exogenous process with a secular trend component $\tilde{Z}_{0} \exp \left(g^{\tilde{z}} t\right)$, with $g^{\tilde{z}}<0$, and a stationary $\operatorname{AR}(1)$ component in $\operatorname{logs}, \log \left(\tilde{a}_{t}\right)=\rho_{\tilde{a}} \log \left(\tilde{a}_{t-1}\right)+\varepsilon_{t}^{\tilde{a}}$ with persistence $\rho_{\tilde{a}}$ and a Gaussian innovation $\varepsilon_{t}^{\tilde{a}}$ with mean zero and variance $\sigma_{\tilde{a}}^{2}$. The downward trending component of oil productivity, $\tilde{Z}_{0} \exp \left(g^{\tilde{z}} t\right)$, is introduced to capture the fact that, over time, the cheaper sources of oil production are exhausted before the more expensive ones.

There is variable capital utilization. In order to operate the installed capital, i.e., to have a capital utilization rate above zero, the representative fringe firm employs the intermediate good $\tilde{X}_{t}$ purchased from the oil-importing region and rents the capital $\tilde{K}_{t}$ from the household given a decreasing returns to scale function. The capacity utilization rate of installed capital is given by

$$
\tilde{u}(X, K) \equiv(X / K)^{\tilde{\gamma}},
$$

so that the oil production technology results in

$$
\tilde{O}_{t}=\tilde{Z}_{t} \tilde{X}_{t}^{\tilde{\gamma}} \tilde{K}_{t-1}^{1-\tilde{\gamma}}
$$

Optimal oil supply by competitive fringe producers implies

$$
\tilde{\gamma} P_{t}=\tilde{X}_{t} / \tilde{O}_{t}
$$

while optimal capital accumulation is given by

$$
1=\beta E_{t}\left[\frac{\tilde{C}_{t}}{\tilde{C}_{t+1}}\left((1-\tilde{\gamma}) P_{t+1} \frac{\tilde{O}_{t+1}}{\tilde{K}_{t}}+(1-\delta)\right)\right],
$$

and optimal bond-holding yields

$$
1=\beta E_{t}\left[\frac{\tilde{C}_{t}}{\tilde{C}_{t+1}}\right] \tilde{r}_{t}
$$


Combining (13) and (14), the short-run supply curve is

$$
\tilde{\gamma} P_{t}=\frac{\tilde{O}_{t}^{1 / \tilde{\gamma}-1}}{\tilde{Z}_{t}^{1 / \tilde{\gamma}} \tilde{K}_{t-1}^{1 / \tilde{\gamma}-1}} .
$$

The region's resource constraint is

$$
P_{t} \tilde{O}_{t}=\tilde{C}_{t}+\tilde{I}_{t}+\tilde{X}_{t}+\tilde{B}_{t}-\tilde{r}_{t-1} \tilde{B}_{t-1}
$$

\section{Dominant oil exporter}

The dominant producer's economy has a structure symmetric to that of fringe producers, except that there is a single oil firm. The firm produces oil, $\hat{O}_{t}$, according to

$$
\hat{O}_{t}=\hat{Z}_{t} \hat{X}_{t}^{\hat{\gamma}} \hat{K}_{t-1}^{1-\hat{\gamma}}
$$

using an imported intermediate good $\hat{X}_{t}$ and capital $\hat{K}_{t-1}$. The dominant supplier's technology evolves deterministically according to $\hat{Z}_{t}=\hat{Z}_{0} \exp \left(g^{\hat{z}} t\right)$ where $g^{\hat{z}}=g^{\tilde{z}}$, that is, unlike the fringe, the dominant supplier's output is not directly affected by productivity shocks. Capital is accumulated by purchasing $\hat{I}_{t}$ units of the investment good from the oil-importing region and the representative household receives a stream of log utility from consumption $\hat{C}_{t}$.

The substantial difference with the competitive fringe is that the dominant oil supplier has market power: it is aware of the dependence of fringe oil supply, of oil demand, and of the equilibrium oil price on its supply decision. The dominant supplier chooses a state-contingent plan which maximizes the expected present discounted utility of its owners, subject to the demand by the oil-importing region, the supply of competitive fringe producers, and clearing in the oil market.

Thus, the decision problem of the dominant oil producer is to

$$
\max _{\hat{C}_{t}, \hat{B}_{t}, \hat{X}_{t}, \hat{K}_{t}, P_{t}} E_{o} \sum_{t=0}^{\infty} \beta^{t} \log \left(\hat{C}_{t}\right)
$$

subject to oil demand (4), fringe oil supply (15), its production technology (17), the oil market clearing condition

$$
O_{t}=\hat{O}_{t}+\tilde{O}_{t}
$$

and its resource constraint

$$
P_{t} \hat{O}_{t}=\hat{C}_{t}+\hat{K}_{t}-(1-\delta) \hat{K}_{t-1}+\hat{X}_{t}+\hat{B}_{t}-\hat{r}_{t-1} \hat{B}_{t-1}
$$


This amounts to assuming that while Saudi Arabia acts as a monopolist supplier of its residual demand in the short-run, it lacks information regarding the long-run (typically secret) investment plans of its competitors and the effect that its decisions may have on labor demand or capital accumulation in the oil-importing region.

The solution to the above problem under commitment yields the following first-order conditions:

$$
\begin{gathered}
1=\beta E_{t}\left[\frac{\hat{C}_{t}}{\hat{C}_{t+1}}\right] \hat{r}_{t}, \\
\hat{\gamma}\left(P_{t}+\Lambda_{t}\right)=\hat{X}_{t} / \hat{O}_{t} \\
1=\beta E_{t}\left[\frac{\hat{C}_{t}}{\hat{C}_{t+1}}\left((1-\hat{\gamma})\left(P_{t+1}+\Lambda_{t+1}\right) \frac{\hat{O}_{t+1}}{\hat{K}_{t}}+(1-\delta)\right)\right],
\end{gathered}
$$

where $\Lambda_{t}$ is the Lagrange multiplier associated with equation (18)

$$
\Lambda_{t}=-\frac{P_{t} \hat{O}_{t}}{\left(\frac{1}{\eta} O_{t}+\frac{\tilde{\gamma}}{1-\tilde{\gamma}} \tilde{O}_{t}\right)}
$$

Notice that equation (20) can be also expressed as

$$
\Lambda_{t}=-\frac{\hat{O}_{t}}{\left(\frac{O_{t}}{P_{t}} \Phi_{D}+\frac{\tilde{O}_{t}}{P_{t}} \Phi_{S}\right)}
$$

where $\Phi_{D} \equiv-\frac{P_{t}}{O_{t}} \frac{\partial O_{t}}{\partial P_{t}}=\frac{1}{\eta}$ is the short-run oil demand elasticity from (4) and $\Phi_{S} \equiv \frac{P_{t}}{\tilde{O}_{t}} \frac{\partial \tilde{O}_{t}}{\partial P_{t}}=\frac{\tilde{\gamma}}{1-\tilde{\gamma}}$ is the short-run fringe supply elasticity from (15).

The dominant oil supplier extracts a pure rent by picking the profit-maximizing point on the residual demand curve, where marginal revenue equals his marginal cost.

\section{Market clearing and balanced growth path}

In equilibrium, all markets clear. There is financial autarky and thus

$$
B_{t}=\tilde{B}_{t}=\hat{B}_{t}=0
$$

Oil market clearing is

$$
O_{t}=\hat{O}_{t}+\tilde{O}_{t}
$$

And goods market clearing is

$$
Y_{t}=C_{t}+I_{t}+\tilde{C}_{t}+\tilde{I}_{t}+\tilde{X}_{t}+\hat{C}_{t}+\hat{I}_{t}+\hat{X}_{t}
$$


The model incorporates secular trends in the growth rate of final goods technology $\left(Z_{t}\right)$, oil production technology $\left(\tilde{Z}_{t}\right.$ and $\left.\hat{Z}_{t}\right)$, and oil efficiency $\left(\nu_{t}\right)$. Stationarity of Saudi Arabia's market share requires $g^{\tilde{z}}=g^{\hat{z}}$. In a steady-state with balanced growth, the ratio $P_{t} O_{t} / Y_{t}$ must remain stationary. Given $g^{\tilde{z}}=g^{\hat{z}}$, since $O_{t}$ grows at rate $g^{z}+g^{\tilde{z}}=g^{z}+g^{\hat{z}}$, while $Y_{t}$ grows at rate $g^{z}$, for the ratio $P_{t} O_{t} / Y_{t}$ to remain stable, $P_{t}$ should grow at rate $-g^{\tilde{z}}$.

\section{Calibration}

We employ the same calibration as in Nakov and Nuño (2014). The working frequency of the model is monthly. The secular growth rate of technology of the oil-importing region is set to $\exp \left(g^{z}\right)=1.03^{1 / 12}$, consistent with an average world output growth rate of 3 percent per year for the period from 1973 to 2009 . Given this, the time preference parameter is set to $\beta=1.01^{-1 / 12}$ equivalent to an average real interest rate of 4 percent per year. Based on the stationary market share of Saudi Arabia in the data, we impose equality between the growth rates of the dominant oil producer and the fringe, $g^{\hat{z}}=g^{\tilde{z}}$. The average growth rate of total oil production is 0.8 percent per year in the data. In the model this must equal the sum of the growth rate of the inputs of oil production, $g^{z}$, and the growth rate of the oil production technology itself, $g^{\tilde{z}}$, implying a value for $\exp \left(g^{\tilde{z}}\right)=0.9982$ on a monthly basis. The latter implies that the real oil price must grow at an annual rate of 2.2 percent, which is consistent with the average growth rate actually observed in the data. Second, the three parameters governing the oil-importing region's labor disutility, technology, and capital depreciation are set to their typical values in the RBC literature: the inverse Frisch elasticity is set to $\omega=1$, the labor share in the production of final goods is set to $\alpha=0.67$; and the depreciation rate is set to $\delta=1.10^{1 / 12}-1$, consistent with $10 \%$ annual depreciation of installed capital. Third, the price elasticity of oil demand in the model is $\frac{P}{O} \frac{\partial O}{\partial P}=\frac{1}{\eta}$. We set $\eta=4$, consistent with Kilian and Murphy's (2014) estimates of the short-run price elasticity of oil demand of about 0.25 . Fourth, the parameters of the two oil production technologies and the efficiency $\left(\tilde{Z}_{0}, \hat{Z}_{0}, \tilde{\gamma}, \hat{\gamma}, \nu_{0}\right)$ are calibrated as follows: $\tilde{\gamma}=0.4, \hat{Z}_{0}=1.8740, \hat{\gamma}=0.5, \nu_{0}=0.0041$. These values allow the model to match an average "oil share in spending" of 5 percent of GDP, as well as the following three averages for Saudi Arabia: a global market share of $12.3 \%$, capacity utilization of $75 \%$, and a price mark-up of $25 \%$.

Regarding the scenarios, the baseline scenario is calibrated so that shale oil production in the Unites States increases from roughly zero in 2010 to $2.7 \mathrm{mb} / \mathrm{d}$ in 2014 and reaches a peak of 4 $\mathrm{mb} / \mathrm{d}$ in 2018 in line with EIA projections. This scenario assumes that current law and regulations affecting the energy sector remain in place throughout the projection horizon. It also assumes that the production of shale oil remains concentrated in the Unites States and does not extend significantly to other countries before 2020. This implies setting the value of the fringe supply shock

$\varepsilon_{t}^{\tilde{a}}$ to 0.0025 from January 2010 until December 2012, then raising it to 0.0040 until December 2017 and reducing it to 0.0030 until December 2019. 
Second, in the lower shale production scenario we consider the case in which technical or environmental constraints limit US shale production which remains broadly flat at $4 \mathrm{mb} / \mathrm{d}$ during the 2014-2018 period. This implies setting the value of the fringe supply shock to 0.0025 from January 2010 to December 2012, then raising it to 0.0040 until November 2013, reducing it to 0.0025 from December 2013 until December 2017 and reducing it again to 0.0030 until December 2019.

In the higher shale production scenario we assume that technological progress and economic incentives push up US shale production, which reaches $6 \mathrm{mb} / \mathrm{d}$ by the end of the decade. This implies setting the value of the fringe supply shock to 0.0025 from January 2010 to December 2012, then raising it to 0.0040 until November 2013, increasing it again to 0.0064 from December 2013 until December 2017 and reducing it to 0.0030 until December 2019.

Finally, in order to analyze the 2014 drop in prices we modify the model in a number of dimensions:

1. Supply shocks. We recalibrate the process $\log \left(\tilde{a}_{t}\right)=\rho_{\tilde{a}} \log \left(\tilde{a}_{t-1}\right)+\varepsilon_{t}^{\tilde{a}}$, with persistence $\rho_{\tilde{a}}=0.8745$ (which is equivalent to 0.2 on an annual basis) and a Gaussian innovation $\varepsilon_{t}^{\tilde{a}}$ with mean zero and variance $\sigma_{\tilde{a}}^{2}=0.05^{2}$.

2. Demand shocks. We introduce a demand shock as a shock to the TFP of oil importers. We have now that $Z_{t}=Z_{t-1} e^{\left(g^{z}+\bar{g}_{t}^{z}\right)}$, where $\bar{g}_{t}^{z}$ is a stochastic process

$$
\log \left(\bar{g}_{t}^{z}\right)=\rho_{z} \log \left(\bar{g}_{t-1}^{z}\right)+\varepsilon_{t}^{z}
$$

with persistence $\rho_{z}=0.9913$ (which is equivalent to 0.9 on an annual basis) and a Gaussian innovation $\varepsilon_{t}^{z}$ with mean zero and variance $\sigma_{z}^{2}=0.01^{2}$.

3. Saudi Arabia shocks. In order to analyze the deviation of Saudi Arabia from its optimal rule, we modify the objective function of the dominant oil producer

$$
\max _{\hat{C}_{t}, \hat{B}_{t}, \hat{X}_{t}, \hat{K}_{t}, P_{t}} E_{o} \sum_{t=0}^{\infty} \beta^{t} \hat{a}_{t} \log \left(\hat{C}_{t}\right)
$$

by introducing a stationary $\operatorname{AR}(1)$ preference shock $\hat{a}_{t}, \log \left(\hat{a}_{t}\right)=\rho_{\hat{a}} \log \left(\hat{a}_{t-1}\right)+\varepsilon_{t}^{\hat{a}}$ with persistence $\rho_{\hat{a}}=0.8254$ (which is equivalent to 0.1 on an annual basis) and a Gaussian innovation $\varepsilon_{t}^{\hat{a}}$ with mean zero and variance $\sigma_{\hat{a}}^{2}=0.05^{2}$. This shock introduces a change in the preferences of the dominant supplier and may be interpreted as a deviation of Saudi Arabia from its profit-maximizing rule. 


\section{Tables and Figures}

Figure 1: US total oil supply (millions of barrels per day). Source: EIA and authors' calculations.

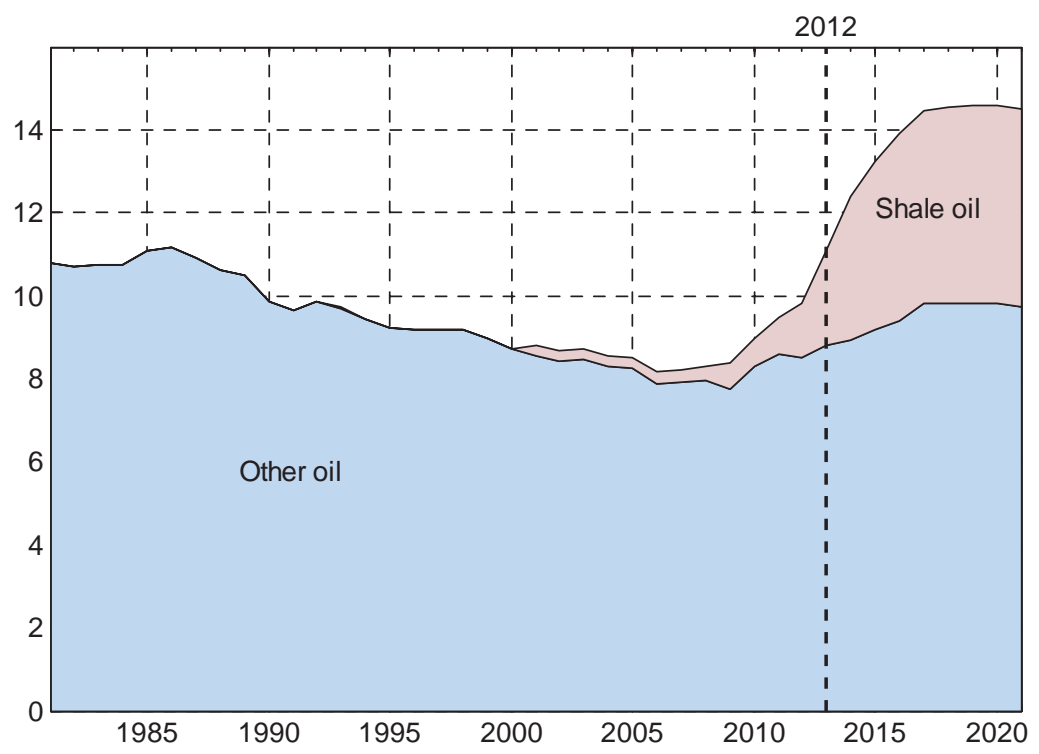

Table 1: Shale oil projections in 2014 and the size of their revisions with respect to the 2013 and 2012 projections.

\begin{tabular}{cccc}
\hline \hline & $\begin{array}{c}\text { Projections AEO 2014 } \\
(\mathrm{mb} / \mathrm{d})\end{array}$ & $\begin{array}{c}\text { Revision since AEO 2013 } \\
(\%)\end{array}$ & $\begin{array}{c}\text { Revision since AEO 2012 } \\
(\%)\end{array}$ \\
\hline 2014 & 4.07 & 62 & 343 \\
2015 & 4.49 & 70 & 361 \\
2016 & 4.67 & 72 & 355 \\
2020 & 4.79 & 70 & 300 \\
\hline \hline
\end{tabular}

Source: EIA Annual Energy Outlook reports 2012, 2013 and 2014. Note that for consistency we label the table as shale oil, although the numbers refer to tight oil projections in the EIA reports. 


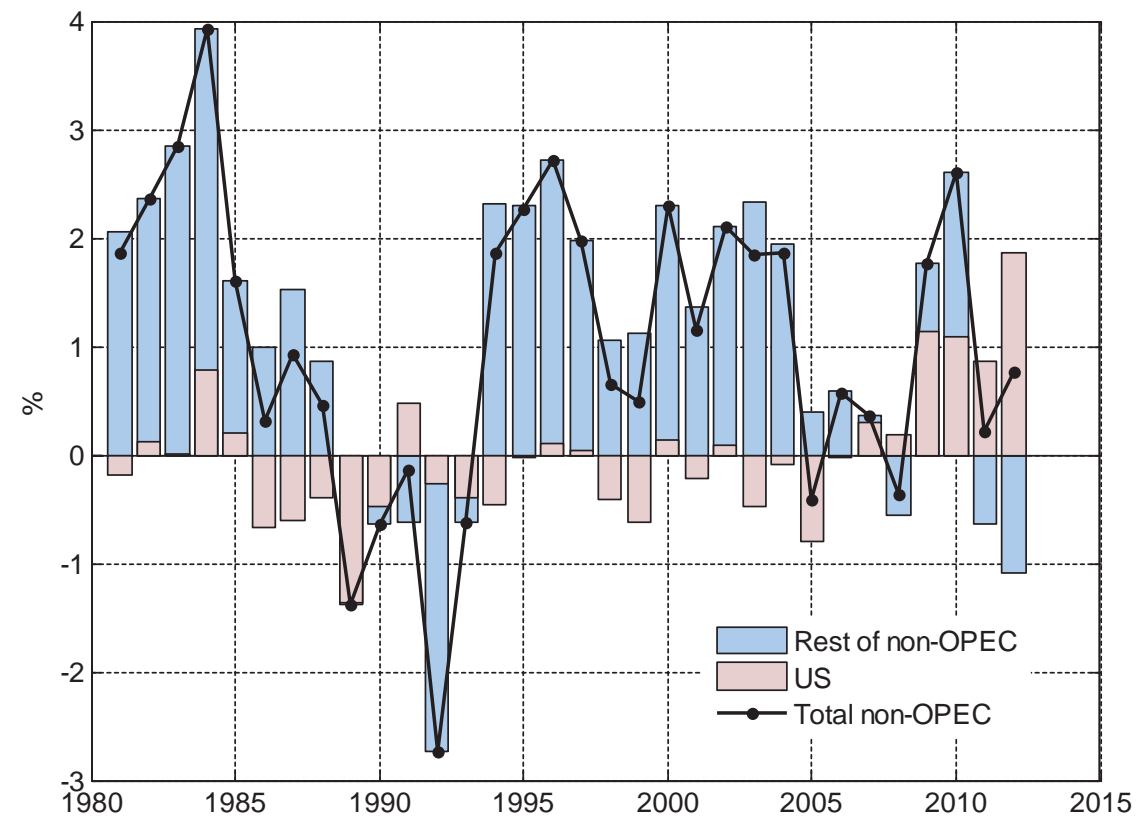

Figure 2: US shale oil contribution to non-OPEC supply growth (annual, y-o-y growth rates). Source: EIA. Note: the last datapoint referes to 2012; cut-off date $2014 \mathrm{H} 1$.
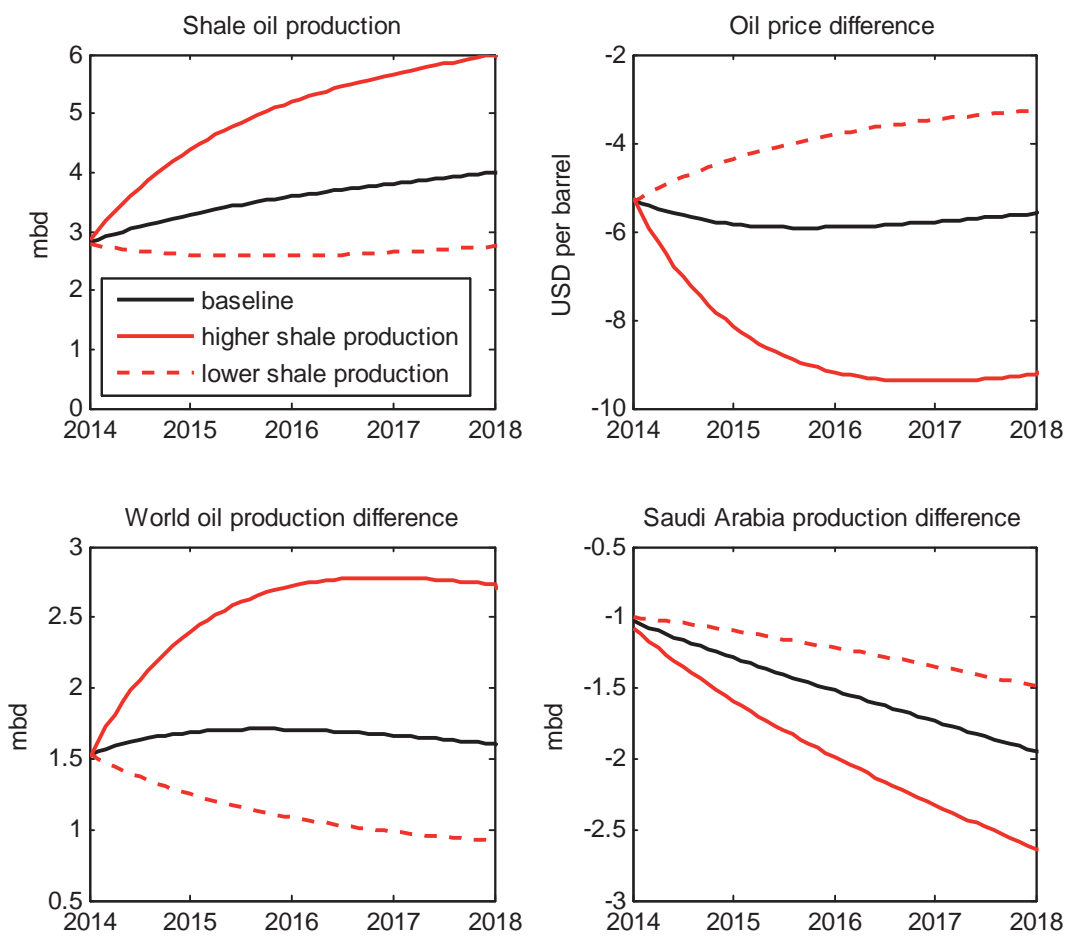

Figure 3: Differential effect of different shale shale production scenarios. All the figures represent differences with respect to the counterfactual scenario of no shale production. 


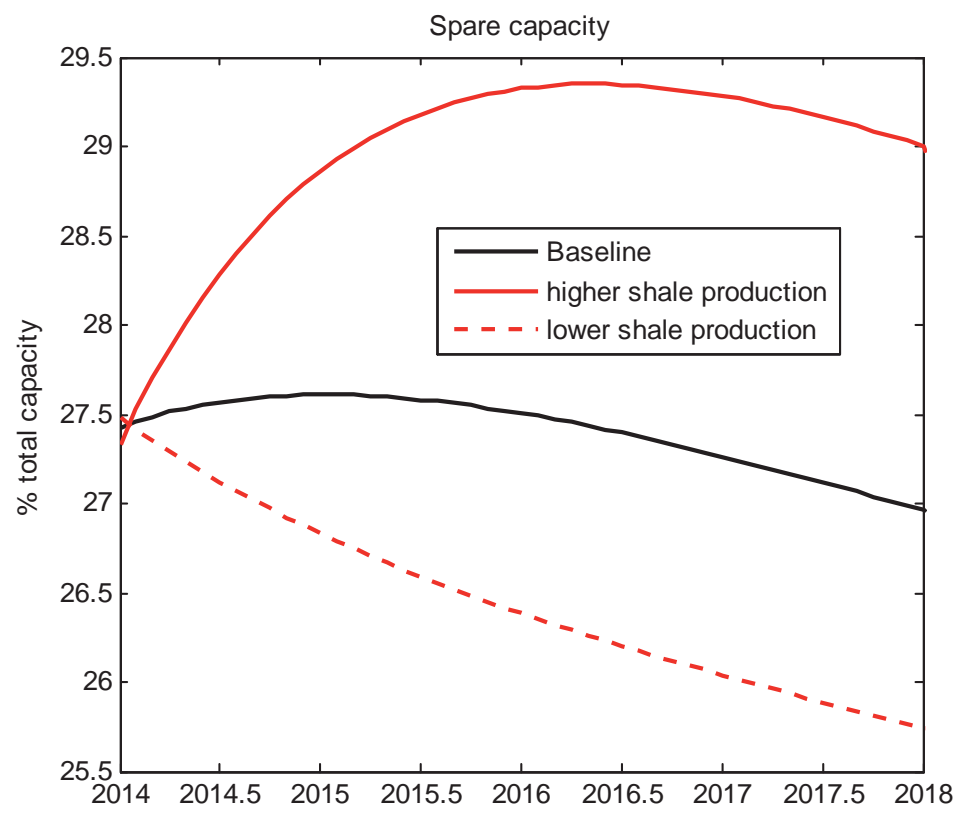

Figure 4: Evolution of the spare capacity of Saudi Arabia (share of total capacity).
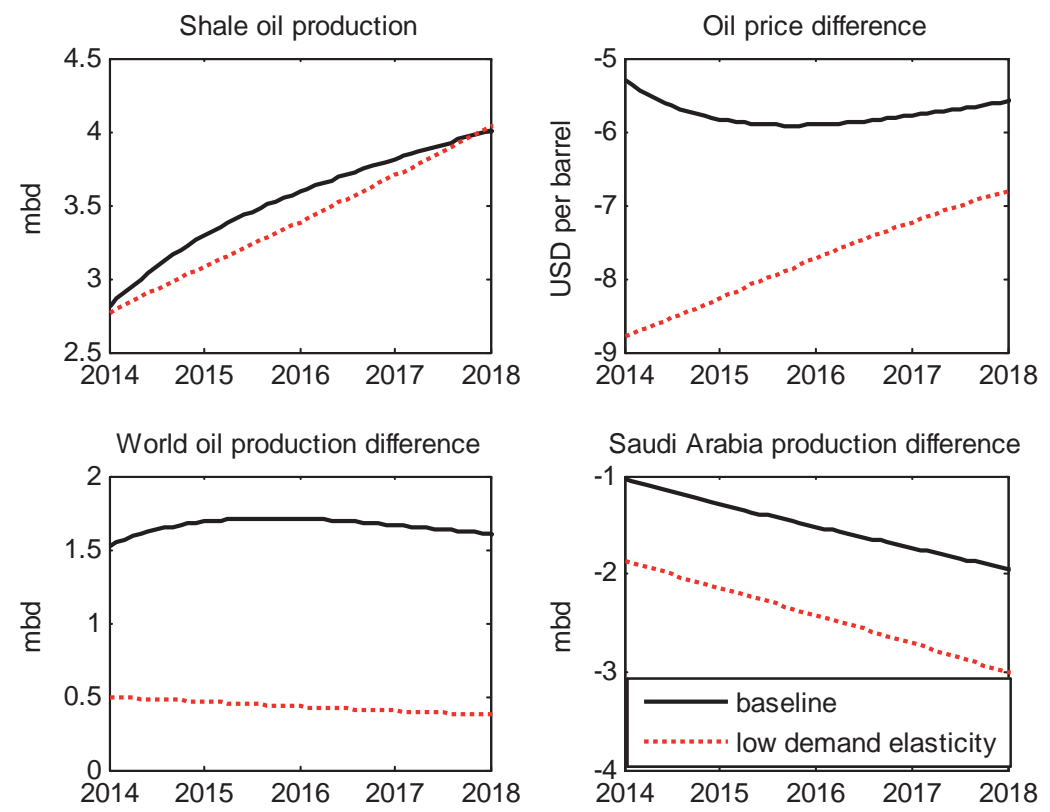

Figure 5: Differential effect of alternative elasticity assumptions. All the figures represent differences with respect to the counterfactual scenario of no shale production. 

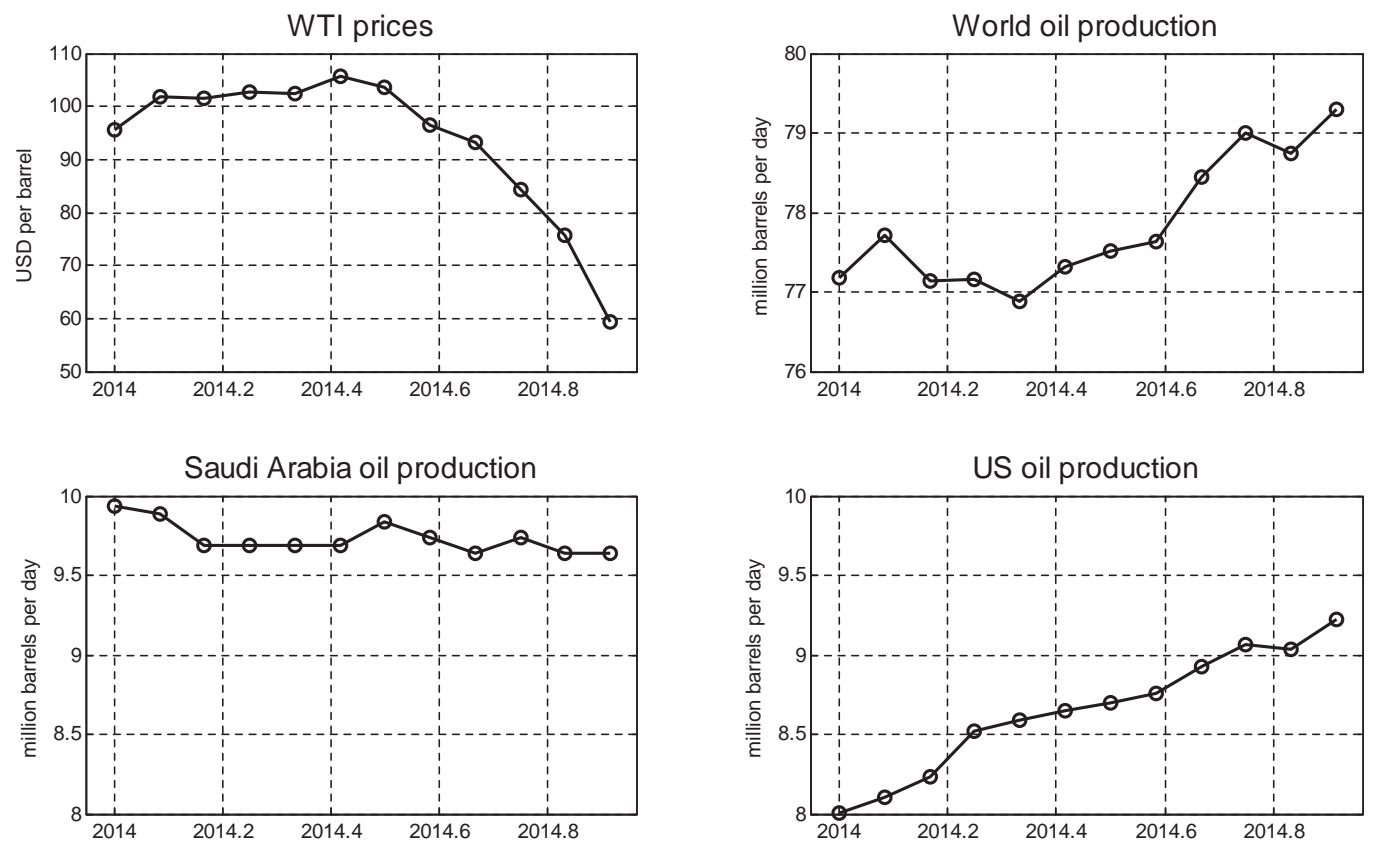

Figure 6: Evolution of oil prices and oil production in 2014. Source: EIA and Federal Reserve Bank of St. Louis.

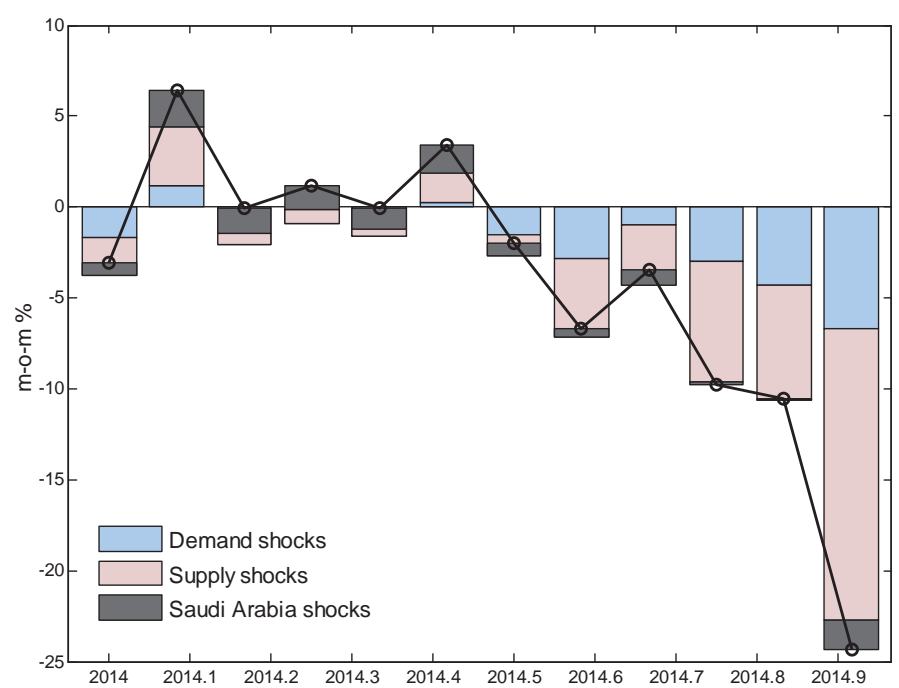

Figure 7: Contributions to the growth rate of oil prices. Source: EIA, Federal Reserve Bank of St. Louis and authors' calculations. 

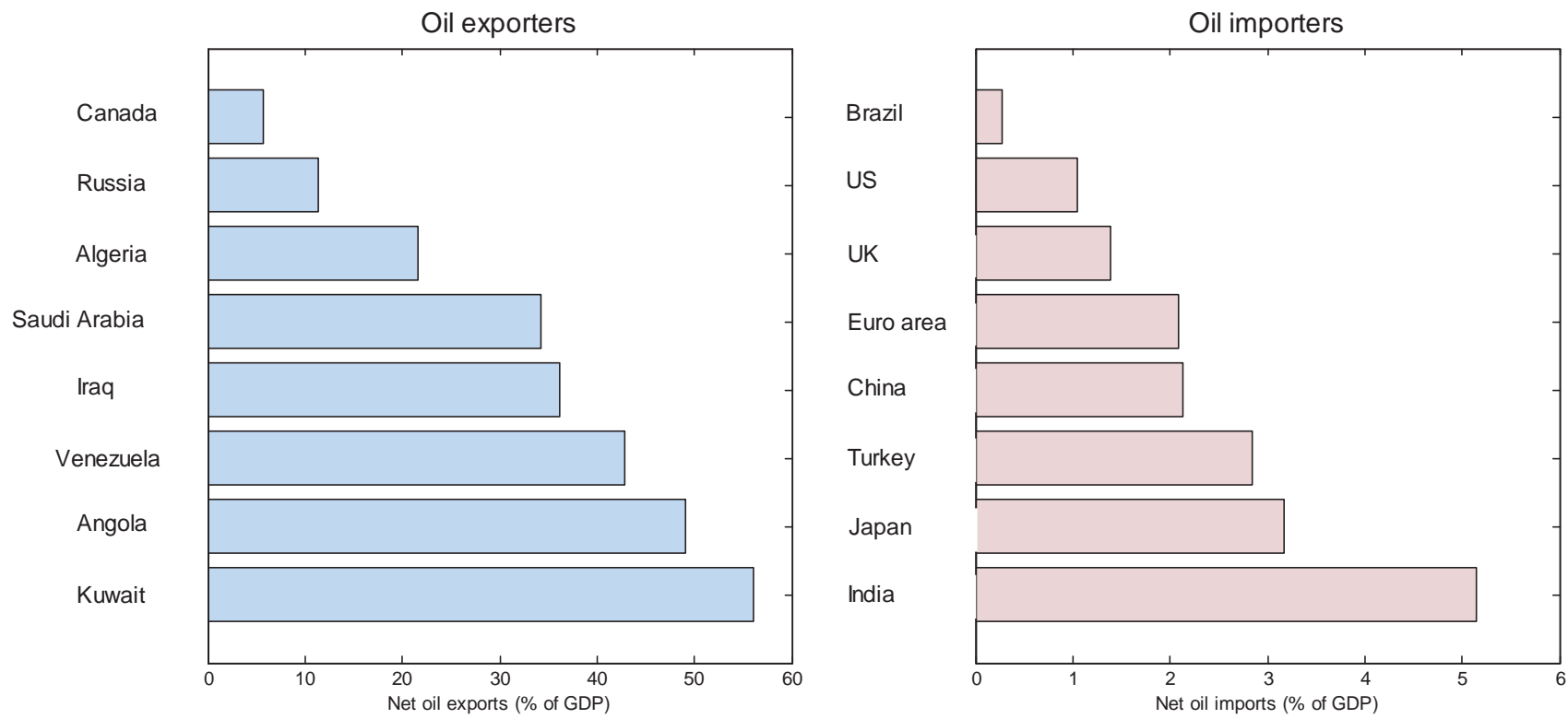

Figure 8: Net oil exports/imports for some of the major exporters/importers. Source: JODI database and IMF. The value of exports/imports is computed for an average oil price of USD100. 


\title{
BANCO DE ESPAÑA PUBLICATIONS
}

\author{
WORKING PAPERS
}

1401 TERESA SASTRE and FRANCESCA VIANI: Countries' safety and competitiveness, and the estimation of current account misalignments.

1402 FERNANDO BRONER, ALBERTO MARTIN, AITOR ERCE and JAUME VENTURA: Sovereign debt markets in turbulent times: creditor discrimination and crowding-out effects.

1403 JAVIER J. PÉREZ and ROCÍO PRIETO: The structure of sub-national public debt: liquidity vs credit risks.

1404 BING XU, ADRIAN VAN RIXTEL and MICHIEL VAN LEUVENSTEIJN: Measuring bank competition in China: a comparison of new versus conventional approaches applied to loan markets.

1405 MIGUEL GARCÍA-POSADA and JUAN S. MORA-SANGUINETTI: Entrepreneurship and enforcement institutions: disaggregated evidence for Spain.

1406 MARIYA HAKE, FERNANDO LÓPEZ-VICENTE and LUIS MOLINA: Do the drivers of loan dollarisation differ between CESEE and Latin America? A meta-analysis.

1407 JOSÉ MANUEL MONTERO and ALBERTO URTASUN: Price-cost mark-ups in the Spanish economy: a microeconomic perspective.

1408 FRANCISCO DE CASTRO, FRANCISCO MARTÍ, ANTONIO MONTESINOS, JAVIER J. PÉREZ and A. JESÚS SÁNCHEZ-FUENTES: Fiscal policies in Spain: main stylised facts revisited.

1409 MARÍA J. NIETO: Third-country relations in the Directive establishing a framework for the recovery and resolution of credit institutions.

1410 ÓSCAR ARCE and SERGIO MAYORDOMO: Short-sale constraints and financial stability: evidence from the Spanish market.

1411 RODOLFO G. CAMPOS and ILIANA REGGIO: Consumption in the shadow of unemployment.

1412 PAUL EHLING and DAVID HAUSHALTER: When does cash matter? Evidence for private firms.

1413 PAUL EHLING and CHRISTIAN HEYERDAHL-LARSEN: Correlations.

1414 IRINA BALTEANU and AITOR ERCE: Banking crises and sovereign defaults in emerging markets: exploring the links.

1415 ÁNGEL ESTRADA, DANIEL GARROTE, EVA VALDEOLIVAS and JAVIER VALLÉS: Household debt and uncertainty: private consumption after the Great Recession.

1416 DIEGO J. PEDREGAL, JAVIER J. PÉREZ and A. JESÚS SÁNCHEZ-FUENTES: A toolkit to strengthen government budget surveillance.

1417 J. IGNACIO CONDE-RUIZ, and CLARA I. GONZÁLEZ: From Bismarck to Beveridge: the other pension reform in Spain.

1418 PABLO HERNÁNDEZ DE COS, GERRIT B. KOESTER, ENRIQUE MORAL-BENITO and CHRISTIANE NICKEL: Signalling fiscal stress in the euro area: a country-specific early warning system.

1419 MIGUEL ALMUNIA and DAVID LÓPEZ-RODRÍGUEZ: Heterogeneous responses to effective tax enforcement: evidence from Spanish firms.

1420 ALFONSO R. SÁNCHEZ: The automatic adjustment of pension expenditures in Spain: an evaluation of the 2013 pension reform

1421 JAVIER ANDRÉS, ÓSCAR ARCE and CARLOS THOMAS: Structural reforms in a debt overhang.

1422 LAURA HOSPIDO and ENRIQUE MORAL-BENITO: The public sector wage premium in Spain: evidence from longitudinal administrative data.

1423 MARÍA DOLORES GADEA-RIVAS, ANA GÓMEZ-LOSCOS and GABRIEL PÉREZ-QUIRÓS: The Two Greatest. Great Recession vs. Great Moderation.

1424 ENRIQUE MORAL-BENITO and OLIVER ROEHN: The impact of financial (de)regulation on current account balances.

1425 MAXIMO CAMACHO and JAIME MARTINEZ-MARTIN: Real-time forecasting US GDP from small-scale factor models.

1426 ALFREDO MARTÍN OLIVER, SONIA RUANO PARDO and VICENTE SALAS FUMÁS: Productivity and welfare: an application to the Spanish banking industry.

1427 JAVIER ANDRÉS and PABLO BURRIEL: Inflation dynamics in a model with firm entry and (some) heterogeneity.

1428 CARMEN BROTO and LUIS MOLINA: Sovereign ratings and their asymmetric response to fundamentals.

1429 JUAN ÁNGEL GARCÍA and RICARDO GIMENO: Flight-to-liquidity flows in the euro area sovereign debt crisis.

1430 ANDRĖ LEMELIN, FERNANDO RUBIERA-MOROLLÓN and ANA GÓMEZ-LOSCOS: Measuring urban agglomeration. A refoundation of the mean city-population size index.

1431 LUIS DIEEZ-CATALÁN and ERNESTO VILLANUEVA: Contract staggering and unemployment during the Great Recession: evidence from Spain. 
1501 LAURA HOSPIDO and EVA MORENO-GALBIS: The Spanish productivity puzzle in the Great Recession.

1502 LAURA HOSPIDO, ERNESTO VILLANUEVA and GEMA ZAMARRO: Finance for all: the impact of financial literacy training in compulsory secondary education in Spain.

1503 MARIO IZQUIERDO, JUAN F. JIMENO and AITOR LACUESTA: Spain: from immigration to emigration?

1504 PAULINO FONT, MARIO IZQUIERDO and SERGIO PUENTE: Real wage responsiveness to unemployment in Spain: asymmetries along the business cycle.

1505 JUAN S. MORA-SANGUINETTI and NUNO GAROUPA: Litigation in Spain 2001-2010: Exploring the market for legal services.

1506 ANDRES ALMAZAN, ALFREDO MARTÍN-OLIVER and JESÚS SAURINA: Securitization and banks' capital structure.

1507 JUAN F. JIMENO, MARTA MARTÍNEZ-MATUTE and JUAN S. MORA-SANGUINEITI: Employment protection legislation and labor court activity in Spain.

1508 JOAN PAREDES, JAVIER J. PÉREZ and GABRIEL PEREZ-QUIRÓS: Fiscal targets. A guide to forecasters?

1509 MAXIMO CAMACHO and JAIME MARTINEZ-MARTIN: Monitoring the world business cycle.

1510 JAVIER MENCÍA and ENRIQUE SENTANA: Volatility-related exchange traded assets: an econometric investigation.

1511 PATRICIA GÓMEZ-GONZÁLEZ: Financial innovation in sovereign borrowing and public provision of liquidity.

1512 MIGUEL GARCÍA-POSADA and MARCOS MARCHETTI: The bank lending channel of unconventional monetary policy: the impact of the VLTROs on credit supply in Spain.

1513 JUAN DE LUCIO, RAÚL MÍNGUEZ, ASIER MINONDO and FRANCISCO REQUENA: Networks and the dynamics of firms' export portfolio.

1514 ALFREDO IBÁÑEZ: Default near-the-default-point: the value of and the distance to default.

1515 IVÁN KATARYNIUK and JAVIER VALLÉS: Fiscal consolidation after the Great Recession: the role of composition.

1516 PABLO HERNÁNDEZ DE COS and ENRIQUE MORAL-BENITO: On the predictability of narrative fiscal adjustments.

1517 GALO NUÑO and CARLOS THOMAS: Monetary policy and sovereign debt vulnerability.

1518 CRISTIANA BELU MANESCU and GALO NUÑO: Quantitative effects of the shale oil revolution.

\section{BANCODEESPAÑA}

Eurosistema
Unidad de Servicios Auxiliares

Alcalá, 48 - 28014 Madrid

E-mail: publicaciones@bde.es www.bde.es 